\title{
KARAKTERISTIK FISIK TANAH TAMBAK GARAM PAMEKASAN
}

\author{
Onie Wiwid Jayanthi ${ }^{a}$,*, Ary Giri Dwi Kartika ${ }^{a}$, Allicya Imelda Putria ${ }^{a}$, Siddiqoh ${ }^{a}$, Siti Rosdyana \\ Silmy ${ }^{a}$, Wafiyudin Syahri Mubarok ${ }^{a}$, Machfud Effendi ${ }^{a}$
}

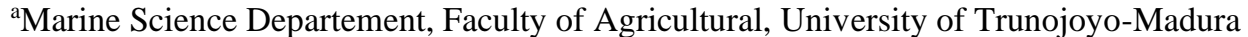 \\ Jl. Raya Telang PO BOX 2 Kamal-Bangkalan, East Java
}

* Koresponden Penulis : onie.jayanti@trunojoyo.ac.id

\begin{abstract}
Abstrak
Garam salah satu komoditas strategis sebab garam merupakan bahan baku industri dan bahan pangan. Salah satu faktor yang mempengaruhi kualitas garam rakyat adalah kondisi fisik tanah tambak garam. Penelitian ini bertujuan untuk mengetahui karakteristik fisik tanah tambak garam di Pamekasan. Metode yang digunakan pada penelitian ini menggunakan metode deskriptif eksploratif yaitu dengan melakukan survei dan pengukuran kualitas serta pengambilan sampel tanah di tambak garam tersebut. Penentuan titik sampel dengan menetapkan tiga titik sampel pada tiap petak tambak garam yaitu pada petak bouzem, peminihan awal ulir, peminihan akhir, dan meja kristalisasi. Warna tanah tiap petak tambak garam menunjukkan warna tua yang mempengaruhi daya serap sinar matahari. Tekstur tanah pada peminihan berupa tanah lempung dan meja kristalisasi berpasir.
\end{abstract}

Kata kunci: karakteristik, warna, tekstur, tanah, tambak, garam

\begin{abstract}
Salt is one of the strategic commodities because salt is an industrial raw material and foodstuff. One of the factors affecting the quality of the people's salt is the physical condition of the salt pond soil. This study aims to determine the physical characteristics of the salt pond soil in Pamekasan. The method used in this study used descriptive exploratory method, namely by conducting surveys and measuring the quality and taking soil samples in the salt pond. Determination of sample points by determining three sample points on each plot of the salt pond, namely the bouzem plot, screw initial selection, final selection, and crystallization table. The soil color of each salt pond shows a dark color which affects the absorption of sunlight. The soil texture in the peminihan is clay soil and sandy crystallization table.
\end{abstract}

Keywords: Characteristics, Color, Texture, Soil, Ponds, Salts

\section{Pendahuluan}

Garam salah satu komoditas strategis, sebab merupakan bahan baku industri dan bahan pangan. Peningkatan kebutuhan garam ditandai dengan jumlah kebutuhan pada tahun 2007 sebesar 2,7 juta ton meningkat sebesar 3,7 ton tahun 2015 [1]. Salah satu problema besar industri garam saat ini adalah tidak terserapnya produksi garam rakyat tahun 2019, sebab industri pengguna menanganggap garam petambak tidak memenuhi standar yang ditetapkan yaitu garam dengan kadar $\mathrm{NaCl}$ di atas 97\% [2].

Salah satu faktor yang mempengaruhi kualitas garam rakyat adalah kondisi fisik tanah tambak garam. Produksi garam rakyat dipengaruhi oleh tekstur tanah pada tambak tersebut [3]. Tekstur tanah berpengaruh dalam tingkat porositas dan mengendapkan bahan pengotor garam pada tambak garam [4].

Teknis produksi tambak garam dengan menggunakan metode yang berbeda yaitu metode tradisional dan metode modern (geomembran) memiliki perbedaan dari kualitas dan kuantitas garam yang dihasilkan,di mana warna garam yang dihasilkan dari metode tradisional (media tanah) memiliki penampakan visual lebih buram dari metode modern, sehingga mempengaruhi kualitas garam yang dihasilkan. Garam yang buram dipengaruhi oleh proses pemanenan garam dengan metode tradisonal (alas tanah) dimana tanah menempel pada garam dan memepengaruhi warna garam tersebut. Tanah mempengaruhi 
kualitas atau kemurnian garam dari kandungan pengotor garam yang dihasilkan. Penampakan garam yang buram menunjukan bahwa garam tersebut memiliki kualitas yang rendah sesuai SNI No 01-3556-2000 [5].

Penelitian ini bertujuan untuk mengetahui karakteristik fisik tanah tambak garam di Pamekasan. Dimana karakteristik fisik tambak garam meliputi tekstur (komposisi penyusun tanah) dan struktur tanah (lapisan atau profil) [6].

\section{MATERI DAN METODE}

Penelitian dilaksanakan bulan September 2020 di tambak garam rakyat dengan teknis produksi menggunkan sistem ulir dan kristalisasi total di Pamekasan. Metode yang digunakan pada penelitian ini menggunakan metode diskriptif eksploratif yaitu dengan melakukan survei dan pengukuran kualitas serta pengambilan sampel tanah di tambak garam tersebut [7].

Penentuan titik sampel dengan menetapkan tiga titik sampel pada tiap petak tambak garam yaitu pada petak bouzem, peminihan awal ulir, peminihan akhir, dan meja kristalisasi. Pengukuran kualitas air dan tanah melipui Dissolved Oxygen (DO), suhu, $\mathrm{pH}$ air dan tanah, $\mathrm{Be}^{0}$.

Pengambilan sampel untuk analisis struktur tanah dilakukan dengan menggunakan alat pipa core sample ukuran 1 $\mathrm{m}$, dimasukkan ke dalam tiap titik yang sudah ditentukan sedalam $50 \mathrm{~cm}$ dari permukaan tanah[8]. Pipa core sample diangkat dan diamati lapisan tanah jika ada perbedaan dengan lapisan atas dan bawah. Sampel tanah tersebut dianalisa warna dan tekstur di Laboratorium Oceanografi Ilmu Kelautan, UTM.

Analisis warna menggunakan pedoman buku Munsell Soil Colour Chart yaitu membandingkan sampel tanah kering 5 gr dan mencocokkan warnanya dengan pedoman tersebut [9]. Untuk analisis tekstur mengacu pada skala Wenworth [10]. Pengamatan tesktur tanah dilakukan pada tiap bagian lapisan tanah yang berbeda yang terperangkap pada pipa core sample. Analisis tekstur tanah dilakukan pada sampel tanah tiap petak dengan tujuan mengetahui perbedaan jenis tanah tersebut.

\section{HASIL DAN PEMBAHASAN}

Teknis produksi garam di Indonesia sebagian besar menggunakan meotde solar evaporation yaitu memanfaatkan sinar matahari untuk mempercepat penguapan sehingga kristal garam dapat terbentuk [11]. Penelitian ini menggunakan tambak garam rakyat yang terdiri dari petakan bouzem, petak peminihan ulir I, peminihan akhir II, dan meja kristalisasi yang dapat dilihat pada Gambar 1 .

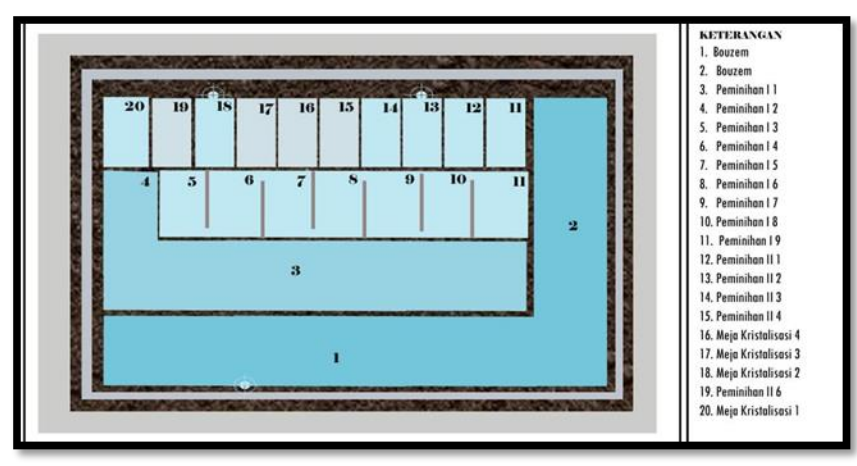

Gambar 1. Petak Tambak Penelitian

(Sumber: Dokumentasi Pribadi, 2020)

Proses produksi tambak garam dimulai dengan mengalirnya air laut ke bouzem (keterangan 1 dan 2 pada Gambar 1), setelah air dalam bouzem mengalami kenaikan $\mathrm{Be}^{0}$ maka akan mengalir ke peminihan ulir (keterangan 3 sampai 11 pada Gambar 1). Dari peminihan ulir akan dialirkan ke peminihan akhir sampai $20^{\circ} \mathrm{Be}$. Pada peminihan akhir akan dialirkan ke meja kritaslisasi sampai terbentuk kristal garam.

Tabel 1. Parameter Kualitas Air dan Tanah Tambak Garam

\begin{tabular}{lccccc}
\hline \multirow{2}{*}{ Letak } & \multicolumn{5}{c}{ Parameter } \\
\cline { 2 - 6 } & $\begin{array}{l}\mathrm{DO} \\
(\mathrm{mg} / \mathrm{l})\end{array}$ & $\begin{array}{l}\text { Suhu } \\
\text { Air }\left({ }^{0} \mathrm{C}\right)\end{array}$ & $\begin{array}{l}\mathrm{pH} \\
\text { Air }\end{array}$ & $\begin{array}{l}\mathrm{pH} \\
\text { Tanah }\end{array}$ & $\mathrm{Be}^{0}$ \\
\hline Bouzem & 12,56 & 32 & 3,9 & 4 & 3 \\
\hline $\begin{array}{l}\text { Peminihan } \\
1 \text { awal }\end{array}$ & 8,34 & 33 & 4,4 & 5 & 4 \\
\hline $\begin{array}{l}\text { Peminihan } \\
1 \text { tengah }\end{array}$ & 11,56 & 35 & 4,6 & 5 & 7 \\
\hline $\begin{array}{l}\text { Peminihan } \\
1 \text { akhir }\end{array}$ & 13,67 & 36 & 4,7 & 4 & 10 \\
\hline $\begin{array}{l}\text { Peminihan } \\
2 \text { akhir }\end{array}$ & 11,79 & 37 & 4,9 & 5 & 15 \\
\hline $\begin{array}{l}\text { Meja } \\
\text { Kristalisasi }\end{array}$ & 14,54 & 39 & 5,5 & 4 & 23 \\
\hline
\end{tabular}


Parameter kualitas air dan tanah tambak garam suhu di tiap petak tambak garam mengalami kenaikan dari bouzem hingga ke meja kristalisasi yang dapat diamati pada Tabel 1. Hal ini dikarenakan pada tiap petak memiliki kedalaman atau ketinggian air yang berbeda dimana saat di meja kristalisasi hanya sekitar $10 \mathrm{~cm}$ untuk mempercepat penguapan sehingga kristal garam cepat terbentuk [12].

Kenaikan boume atau $\mathrm{Be}^{0}$ pada tiap petak (Tabel 1) dipengaruhi oleh ketinggian air, kolam petak tambak, keadaan cuaca, intensitas sinar matahari, curah hujan, kelembaban, kecepatan angin, dan kelembaban udara. Jika sudah sampai tahap kristalisasi maka nilai $\mathrm{Be}^{0}$ juga meningkat. Nilai $\mathrm{pH}$ air tambak juga semakin meningkat dari bouzem hingga ke meja kritalisasi (Tabel 1) sebab dengan adanya kenaikan $\mathrm{Be}^{0}$ kadar garam menjadi tinggi sehingga nilai $\mathrm{pH}$ menunjukkan basa.

Pada pengamatan struktur tanah tiap petak tambak garam menggunana pipa core sample didapatkan beberapa petak memilki dua lapisan struktur tanah yang berbeda. Struktur tanah pada petak tambak garam mempengaruhi tingkat permeabilitas tanah [13]. Daya permeabilitas ini sangat baik untuk petak tambak agar air tidak mudah terserap masuk ke dalam tanah.

Tabel 2. Struktur dan Tekstur Tanah Petak Tambak Garam

\begin{tabular}{lccc}
\hline \multicolumn{1}{c}{ Letak } & Lapisan & Tesktur & Warna \\
\hline Bouzem & 1 & Clay sand & Dark Gray \\
\hline $\begin{array}{l}\text { Peminihan } \\
1 \text { awal }\end{array}$ & 1 & Silty sand & Gray \\
\hline $\begin{array}{l}\text { Peminihan } \\
1 \text { tengah }\end{array}$ & 2 & Silty Sand & $\begin{array}{c}\text { Very Dark } \\
\text { Gray }\end{array}$ \\
\hline $\begin{array}{l}\text { Peminihan } \\
1 \text { akhir }\end{array}$ & 1 & Sand & Gray \\
\hline $\begin{array}{l}\text { Peminihan } \\
\text { akhir }\end{array}$ & 1 & Silty Sand & $\begin{array}{c}\text { Very Dark } \\
\text { Gray }\end{array}$ \\
\hline & 2 & Silty Sand & $\begin{array}{c}\text { Grayish } \\
\text { Brown }\end{array}$ \\
\hline $\begin{array}{l}\text { Meja } \\
\text { Kristalisasi }\end{array}$ & 1 & Sand \\
\hline
\end{tabular}

Tekstur tanah pada tiap petak tambak penelitian dapat dilihat pada Tabel 2 dimana pada petak bouzem tekstur berupa lempung berpasir, petak peminihan ulir awal dan akhir yaitu tanah pasir dan tanah lempung. Petak peminihan akhir memiliki tekstur tanah lempung dan meja kristalisasi berupa tanah pasir. petak bouzem tekstur berupa lempung berpasir, petak peminihan ulir awal dan akhir yaitu tanah pasir dan tanah lempung. Petak peminihan akhir memiliki tekstur tanah lempung dan meja kristalisasi berupa tanah pasir [14].

Tiap petak tambak garam diambil tiga titik sampel tanah untuk dianalisa kenampakan warna tanah (Tabel 2). Warna tanah di petak bouzem berupa abu-abu dan abu kecoklatan. Untuk petak peminihan ulir awal warna tanah cenderung abu kecoklatan dan peminihan ulir akhir cenderung abu-abu tua. Warna tanah petak peminihan akhir yang akan masuk ke meja kristalisasai yaitu abuabu sangat tua. Sedangkan warna tanah pada meja kristalisasi cenderung ke abu-abu tua.

Warna abu tua yang cenderung kehitaman pada petak tambak garam menunjukkan tigkat daya serap panas sinar matahari tinggi sehingga proses penguapan pada petak tersebut menjadi tinggi [15]. Dengan kondisi warna petak tambak tersebut yang cenderung tua memberikan kontribusi terhadap laju penguapan air pada petak tambak sehingga kenaikan kadar garam $\left({ }^{0} \mathrm{Be}\right)$ menjadi lebih cepat.

\section{KESIMPULAN}

Parameter kualitas air pada tiap tambak garam dari bouzem, peminihan ulir, peminihan akhir dan meja kristalisasi memiliki nilai yang berbeda akibat adanya perbedaan ketinggian air pada kolam tambak dan proses penguapan untuk peningkatan kadar garam ditambak tersebut.

Warna tanah tiap petak tambak garam menunjukkan warna tua yang mempengaruhi daya serap sinar matahari. Tekstur tanah pada peminihan berupa tanah lempung (permeabilitas rendah) dan meja kristalisasi berpasir (permeabilitas tinggi). 


\section{DAFTAR PUSTAKA}

[1] Kementerian Kelautan dan Perikanan (KKP). 2015. Data Neraca Garam Periode Tahun 2009 - 2015.

[2] Komisi Pengawas Persaingan Usaha Republik Indonesia. 2020. KPPU Sarankan Perubahan Tataniaga Garam. Siaran Pers No. 04/KPPU-PR/I/2020.

[3] Balai Besar Litbang Sumber Lahan Pertanian. Badan Penelitian dan Pengembangan Departemen Pertanian. 2006. Sifat Fisik Tanah dan Metode Analisinya. Balai Besar Litbang Sumber Lahan Pertanian. Badan Penelitian dan Pengembangan Departemen Pertanian

[4] Setiawan, W. "Studi Kesesuaian Wilayah Pesisir Sebagau Lahan Tambak Garam di Kecamatan Palang Kabupaten Tuban". Prosiding Seminar Nasional Hasil Penelitian dan Pengabdian kepada Masyarakat III. Universitas PGRI Ronggolawe Tuban. Print ISSN: 25803913; Online ISSN: 2580-3921. 2018

[5] Efendy, M, Zainuri M., dan Hafiluddin. "Intensifikasi Lahan Garam Rakyat di Kabupaten Sumenep". Jurnal Ilmu Kelautan. 2015.

[6] Dairy Soils and Fertiliser Manual Team. "Dairy Soils and Fertiliser Manual: Australian Nutrient Management Guidelines".www.fertsmart.dairyaustrali a.com.au. page 4-2 - 4- 17. publikasi June 2013.

[7] Arikunto, Suharsimi. "Prosedur Penelitian Suaru Pendekatan Praktik". PT. Rineka Cipta. Jakarta. 2010.

[8] Siddique, M.A.M., Barua, P., dan M. H. Ghani.""Comparative Study of Physicochemical Properties of Soil According to The Age of Aquaculture Pond of
Bangladesh". Mesopot. J. Mar. Sci., 2012, 27 (1): 29 - 38.

[9] Chusyairi, A. "Aplikasi E.Soil untuk Mengidentifikasi Warna Tanah Berbasis Android Menggunakan Munsell Soil Color Chart". TEKNOMATIKA, Vol.09, No.01, Maret 2019. P-ISSN : 2087-9571, E-ISSN : 2541-335X

[10] Folk, R.L.. "A review of grain-size parameters". Sedimentology, 6: 73-96. 1966.

[11] Wiraningtyas A, Sandi A, dan Ruslan. "Teknologi Pengolahan Garam Beryodium melalui Solar Thermal Salt House di Desa Sanolo". Jurnal Mitra. Vol.3. No.1, Mei 2019. Lembaga Penelitian dan Pengabdian Masyarakat. Unika Atma Jaya. 2019

[12] Ulfidatul YH. "Peningkatan Kualitas Produksi Garam Menggunakan Teknik Geomembran". JSMB Vol. 6 (2) 2019 hlm. 35-42. Jurnal Studi Manajemen dan Bisnis. 2019.

[13] Prasetyo, BH. 2007. "Perbedaan SifatSifat Tanah Vertisol dari Berbagai Bahan Induk". Jurnal Ilmu-Ilmu Pertanian Indonesia. Volume 9, No. 1, 2007, Hlm. 20 - 31. 2007

[14] Dinas Kelautan dan Perikanan. "Buku Panduan Pengembangan Usaha terpadu garam dan Artemia". Pusat Riset Wilayah Laut dan Sumberdaya Nonhayati Badan Riset Kelautan dan Perikanan Departemen Kelautan dan Perikanan. Jakarta. 2007

[15] Handayani, S dan Karnilawati. "Karakteriktik dan Klasifikasi Tanah Ultisol di Kecamatan Indrajaya Kabupaten Pidie". Jurnal Ilmiah Pertanian Vol. 14 No.2. 2018 